\title{
The Perceived Corrupt Practices of Academics: What Conditions Promote Them?
}

\author{
Kuranchie, Alfred \\ Lecturer, Faculty of Education, \\ Catholic University College of Ghana \\ Twene, Charles \\ Senior Research Assistant, Faculty of Education, \\ Catholic University College of Ghana \\ Mensah, Monica Konnie \\ Lecturer, Faculty of Education, \\ Catholic University College of Ghana \\ Arthur, Charles \\ Acting Librarian, \\ Catholic University College of Ghana
}

\section{Doi:10.5901/ajis.2014.v3n1p189}

\section{Abstract}

The study delved into corrupt practices perceived to be pervasive in academic institutions especially that of academics. The exercise was motivated by the paucity of information on where the alleged practice emanates from and the conditions in academic institutions perceived to be promoting the practice. The cross-sectional survey utilised students from two universities in Ghana. Questionnaire was the main research instrument used for the data gathering. The instrument was validated through peer review and pilot testing and the data was analysed using SPSS version 20. The study disclosed that students perceived favouritism, nepotism and examination malpractices to be the major forms that corruption of academics takes in the institutions and the majority of the respondents perceived staff to be the initiators of the acts. The survey also revealed that majority of the respondents believed that fear of victimization, fear of school authority and bureaucracy in dealing with such issues are some conditions that promote the perpetuation of the acts in the institutions. The study, therefore, recommends an enactment and enforcement of codes of conduct in the institutions to ensure high ethical standards. It is envisaged that the study would be beneficial to the Ministry of Education, university authorities, academic staff, and students of tertiary educational institutions.

Keywords: perceived corruption, forms of corrupt practices, academic institutions, initiators of corruptible acts and conditions that promote corruption.

\section{Introduction}

In recent times, the issue of corruption has become topical and headline news in most economies and at the international level although the practice is believed to have existed long ago. Carr (2011) opines that corruption as a phenomenon has always existed but in recent years the awareness of it has grown at the international level. The serious and extensive discourse about the subject has arisen probably because of its devastating effects on the individual and the society in general. According to the African Union (as cited in Hallack and Poisons, 2007), in 2002, corruption was estimated to, directly and indirectly, cost Africa some 25\% of its Gross Domestic Product (GDP). The World Bank puts the costs of corruption at 1 trillion dollars (\$1,000 billion) per year, in a total global economy of 30 trillion dollars (Kaufmann, 2005). It flows from these that, if frantic efforts had not been made by leaders to curb the menace, the cost of corruption to the African continent and the world economy might have doubled, if not tripled by now. Iddrisu (2003) opines that corruption kills initiative and rewards lazy people; corruption weakens society as it hampers the equitable distribution of values and the operation of justice; and it violates public trust and corrodes social capital.

Corruption as a conundrum has been a canker worm which has eaten deeply into the fabric of the society. Most 
countries are reported to be plagued with corruption and its concomitant effects on their people and economies. Nnodum (2008) asserts that the issues of corruption and people's involvement in the practice have become an endemic and cancerous menace plaguing and interfering with all facets of development and levels of human existence in Nigeria. The situation is not different in Ghana hence Iddrisu (2003) contends that the culture of corruption has become part and parcel of the public service of Ghana. To him, corruption had become a norm rather than an exception. According to Mensah, Aboagye, Addo and Buatsi (2003), a survey conducted in Ghana revealed that majority of Ghanaians considered corruption as a serious problem and most public agencies were rated low in terms of honesty and integrity. The findings of the Transparency International Ghana (Ghana Integrity Initiative) study on perceived corrupt practices corroborated the above respective observation and finding. The Transparency International Ghana (2011) survey reported that the majority of the respondents indicated that corruption was a serious problem in the country and they lamented that corruption had been increased over the last three years.

The various sectors of most economies including the education sector are said to be experiencing this ugly act. Meier and Griffin (2005) contend that corruption occurs at the tertiary educational institutions where its consequences are particularly damaging since future economic and political leaders are trained there. Graduates trained at this level of education end up taking appointments at the top echelons of the various sectors of the world's economies so if they are affected by corrupt activities at the university one can envisage the sort of behaviour they would exhibit at the world of work. Temple and Petrov (2004) observed that corruption in higher education is widespread in the states of the former Soviet Union. Heyneman, Anderson and Nuralyeva (2007) investigated the relationship between corruption and educational outcomes in 50 countries. The investigation revealed that corruption is negatively associated with educational outcomes. Shelley (2003) observes that corruption in academic institutions has the tendency to reduce the ethical values of students. When students realise that personal success depends not on performance but on bribery, favouritism and nepotism, then they would develop unethical behaviour, which can be passed on to the next generation. Rumyantseva (2005) also asserts that if students realise that corruption is acceptable and even a way of life, they may be more inclined to carry this behaviour to all aspects of life. The author adds that corruption in education negatively affects the welfare of a society by bringing up distorted values in the youth. Regrettably, universities which are supposed to be citadel of learning for producing people with sound knowledge, character and integrity have also become centres of producing highlevel dishonest and corrupt persons (Nnodum, 2008).

Hallack and Poison (2007) assert that corruption and corrupt practices pose a threat to the successful achievement of national educational goals. Corruption has the tendency to dwindle the resources available to educational institutions, limit access to education and reduce quality of services offered by the institutions. Heyneman (2009) also opines that corruption affects three aspects of education which are access, equity and quality. Corrupt practices have a high propensity to negatively affect the moral, emotional and social formation of the students who are affected by it. The seriousness of the consequences of the practice has occasioned studies by governments, international bodies and individual researchers to fully understand the phenomenon so as to prescribe appropriate antidotes to it. It is important that all aspects of the issue of corruption of academics ought to be explored extensively through empirical studies. This underscores the need to unravel conditions in educational institutions that promote the cancerous menace as well as the party to the phenomenon which mostly initiates the acts.

\subsection{Problem Statement}

Perceived corrupt practices are observed to have become intractable in educational institutions. The practice has the tendency to make universities fail to achieve their goal of developing competent and morally upright people for socioeconomic and political development of nations. The moral upbringing of students of tertiary educational institutions is paramount to the sustainability and development of the societies they are being trained for. The alleged acts of corruption have the tendency to negatively influence the students who are affected by the acts. There is the tendency for the graduates to carry the animosities that results from the corruption experiences they encounter at school to their places of work to the detriment of the societies and the innocent people that their work activities would affect.

Although some studies have been conducted on the issue of corruption of academics and in educational institutions to understand it in order to prescribe appropriate solutions to it, some grey areas existed in extant literature that needed attention. It was realised that literature on corruption did not provide sufficient data on the initiators of the alleged corrupt practices in academic institutions and the conditions that serve as fertile grounds for the acts to be perpetuated. It is imperative to note that the fight against corruption of academic staff will succeed, largely, only when the initiators of the acts are known. This is because knowing the initiators would help authorities fashion appropriate 
counselling and education programmes and activities for the right party to the practice. Again, any attempt to adequately understand and fight the perceived corruption in academics requires ascertaining conditions in the university system that promote it in order to help fashion cogent policies to address the menace. The study, therefore, purported to ascertain the initiators of the perceived corruption activities of academics, the forms that the acts take and the conditions in the system that enhance the perpetuation of the acts.

\section{Literature Review}

\subsection{Corruption Defined}

The concept corruption defies one definition. Fasokun (2010) defines corruption as a behaviour which exploits human person, disdainfully uses men and women for selfish interests. The person who exhibits such a behaviour gains at the detriment of the other party. Corruption is a problem of routine deviation from established standards and norms of public officials and parties they interact with (Ruzindana, 1999). Kassahu (2011) asserts that corruption is a price, reward and gift or favour bestowed with or promised with the view to perverting justices. He contends that in whatever way corruption is defined it entails acts which are perceived to be against public interest or violate certain legal or moral laws and principles and some of these are directly or indirectly harmful to the society. Iddrisu (2003) also contends that bribery and corruption are forms of deviant behaviours which involve both a state of moral turpitude and an attempt to by-pass laid down procedures. Patrinos and Ruthkagia (2007) also assert that corruption acts include bribery, extortion, influence peddling, nepotism, fraud, influence officials to take specific actions and embezzlement. Hallack and Poison (2007) also postulate that academic corruption is a systematic use of public office for private benefits, which impact is significant on the availability and quality of educational goods and services.

\subsection{Perceived Corrupt Practices in Academic Institutions}

Corrupt practices are human behaviours or acts that deviate from the norms and values of the society or which tend to break certain moral or social codes and administrative rules and procedures (Lawal, 2006). These acts are not in consonance with the acceptable practices of societies, institutions and groups. A litany of corrupt practices have been found to exist in academic institutions some of which are fraud, embezzlement, bribery, smuggling, sexual abuse, examination malpractices, distorting of grades, over use of power, and certificate forgery (Eze, 2006, Lawal, 2006). These are unacceptable practices and behaviours which members of staff are alleged to engage in as they execute their duties in their academic institutions. A review of literature also reveals that sexual harassment, favouritism, examination malpractices, admission malpractices, compelling students to buy handouts or extortion, neglect of duty, certificate forgery, among others, are the common corrupt practices pervasive in the universities (Nnodum, 2008).

Studies have been conducted to ascertain corruption of academics in some countries. Alutu and Alutu (2006) study explored unethical practices in the faculties of the University of Benin, Nigeria. The study discovered that unethical practices are generally prevalent in all the faculties. It also emerged from the study that the views of the male respondents did not differ significantly from those of their female counterparts on unethical practices of academic staff of the university. A similar study was conducted in the Imo State University in Nigeria on various corrupt practices alleged to be engaged in by academic staff. The study disclosed that students perceived the academic staff to engage in corrupt practices such as money for selfish purposes, overuse of power, sexual harassment, examination malpractices, nepotism and favouritism, and certificate forgery. The study also found that the male and female respondents did not differ in their perceptions of corrupt practices of the academic staff (Nnodum, 2008).

On the issue of which gender group is perceived to be more corrupt, a study by Swamy, Knack, Lee, and Azfar (2000) unearthed that women tended to be significantly less corrupted than men. The study explored the determinants of bribery at both macro and micro levels in 50 countries. Among other things, the study revealed that countries and firms with a greater proportion of women in the labour force tended to have lower levels of corruption. A study by Mocan (2004) also found a relationship between corruption and gender and concluded that men are more likely to be asked for bribe than women. The results of Calelkora and Hanousek (2004) study on corruption perception and willingness to pay bribe showed no relationship between gender and willingness to pay bribe in educational institutions. Shaw (2005) also investigated the determinants of corruption in higher educational institutions in Ukraine. The study revealed a striking perception among the respondents that women tended to have a higher probability of bribery on examinations and for entrance into the institutions than men. This finding is apparently inconsistent with Mocan (2004) and Swamy et al (2000) 
studies which disclosed that women tended to be less significantly corruptible than men.

A study conducted by Swamy (2005) also found that bribery during secondary school was a predictor of bribing for entrance into tertiary institutions and on term papers. The results of the study imply that students who involved themselves in bribery and other corruptible practices at the secondary school were very likely to do so at the tertiary level of education and vice versa. This imposes a responsibility on instructors at the high school level to curb this practice so that it does not continue and even escalate at the higher level of education.

An international organisation, Transparency International, has also conducted several studies into corrupt practices in academic institutions of different countries. For instance, Transparency International Bosnia and Herzegovina conducted an opinion poll among university students at the Bosnia's two main universities. The following were found to be the most common forms of corruption perceived by the students: bribes for passing examination, compulsory purchase of textbooks written by lecturers and buying and selling of diplomas. Transparency International Georgia also discovered that higher education institutions in Georgia were plagued with corruption acts such as students buying their admissions, grades and diplomas (Meier \& Griffin, 2005). Heyneman (2010) reported, inter alia, that Transparency International monitoring of corruption in education shows that $70 \%$ of the respondents in Middle East described educational systems as being either "corrupt" or "extremely corrupt". The findings further elaborate that the corruption perception in the region was deemed to be very high.

The foregoing studies present a panorama of the various aspects of the perceived corruption endemic in higher educational institutions that have been investigated. It is very conspicuous that the initiators of the act and the conditions in the institutions that give way for the perpetuation of the act, however, have not been explored. Hence, the need for a study to unravel these issues to extend knowledge on this all-important subject became eminent.

\subsection{Research Questions}

Three questions were gleaned from literature to guide the study.

1. What forms does the perceived corruption of academics take in the institutions?

2. What are the perceived conditions in the institutions that promote the practices?

3. Who are the initiators of the perceived corrupt practices?

\subsection{Hypothesis}

The study tested one hypothesis

Ho1: There is no significant difference in the male and female students' perception of the initiators of the corrupt practices in the institutions

\section{Methodology}

\subsection{Design}

Explorative survey design was adopted for the study. The study was designed alone quantitative dimension. This made it possible to sample a large number of students to express their views on the issues under investigation.

\subsection{Population and Sample}

Students of the two universities constituted the population of the study. Stratified and convenience sampling techniques were employed to sample the respondents. The male and female groups constituted the two strata from which the samples were selected. Due to the nature of the subject investigated, convenience sampling technique was employed in selecting the respondents. Eventually, the study used 330 students to constitute the sample size.

\subsection{Instrumentation}

The sole instrument that was developed and used for the study was a questionnaire titled Students' Perception of Corrupt Practices of Academics (SPPCA). As a researcher-developed instrument, it was validated through peer review after which it was pilot-tested to ascertain its reliability. The reliability co-efficient was $r=0.78$ which was deemed to be good for 
the main study. The research instrument had mainly close-ended items for the students to provide relevant data for the study.

\subsection{Data Analysis}

The data was thoroughly edited before the analysis. The research questions were answered using descriptive statistics in the form of percentages and frequency counts while the hypothesis was tested using inferential statistics like independent t-test. The hypothesis was tested at significance level of 0.05 .

\section{Results of the Study}

This section of the write-up presents and discusses the data gathered from the research.

Table 1: Gender Distribution of Respondents

\begin{tabular}{ccc}
\hline & Freq. & Percent (\%) \\
\hline Male & 201 & 60.9 \\
Female & 129 & 39.1 \\
\hline Total & 330 & 100 \\
\hline
\end{tabular}

The data in Table 1 demonstrate that the male respondents constituted the majority of the sample forming almost sixtyone percent (61\%) while the female respondents formed the minority constituting approximately thirty-nine percent (39\%). Implicitly, more male students were used in the study to express their views on the alleged corruption and corruptible acts in academic institutions than female students.

The study sought to ascertain the forms that the perceived corruption takes in the institutions. The results are presented in Table 2.

Table 2: Forms of Perceived Corruption in Academic Institutions

\begin{tabular}{lcccccccc}
\hline & \multicolumn{2}{c}{ Agree } & \multicolumn{3}{c}{ Not Sure } & \multicolumn{2}{c}{ Disagree } & \multicolumn{3}{c}{ Total } \\
& Freq. & $\%$ & Freq. & $\%$ & Freq. & $\%$ & Freq. & $\%$ \\
\hline Abuse of office & 100 & 30.3 & 97 & 29.4 & 143 & 40.3 & 330 & 100 \\
Favouritism & 180 & 54.5 & 66 & 20.1 & 84 & 20.1 & 330 & 100 \\
Nepotism & 192 & 58.1 & 55 & 16.7 & 83 & 25.2 & 330 & 100 \\
Examination malpractices & 155 & 49.7 & 42 & 17.7 & 124 & 37.6 & 330 & 100 \\
Sexual harassment & 101 & 30.6 & 105 & 31.8 & 124 & 37.6 & 330 & 100 \\
Forcing students to buy reading materials including handouts & 120 & 36.3 & 63 & 19.2 & 147 & 44.5 & 330 & 100 \\
Engaging in certificate forgery & 25 & 2.0 & 115 & 34.9 & 190 & 57.5 & 330 & 100 \\
Embezzlement of money & 72 & 21.9 & 110 & 33.3 & 148 & 44.8 & 330 & 100 \\
Fraud in admission & 44 & 13.3 & 123 & 37.3 & 163 & 49.9 & 330 & 100 \\
\hline
\end{tabular}

The results of the survey disclosed that majority of the students (54.5\%), (58.1\%) and (49.7\%) respectively perceived that favouritism, nepotism and examination malpractices are the major forms of corruption prevailing in the institutions. These imply that majority of the students perceive corruption to take the forms of favouritism, nepotism and examination malpractices in the institutions. The results also show that a good percentage of the students (30.3\%), (30.6\%) and $(36.3 \%)$ respectively perceived abuse of office, sexual harassment and forcing students to buy reading materials as also forms of corruption in the institutions.

The study also sought to ascertain conditions in the institutions perceived to be encouraging the perpetuation of corruption and corruptible practices. The results are presented in Table 3. 
Table 3: Conditions that Promote Corruption in Academic Institutions

\begin{tabular}{lcccccccc}
\hline & \multicolumn{2}{c}{ Agree } & \multicolumn{2}{c}{ Not Sure } & \multicolumn{2}{c}{ Disagree } & \multicolumn{3}{c}{ Total } \\
& Freq. & $\%$ & Freq. & $\%$ & Freq. & $\%$ & Freq. & $\%$ \\
\hline Lack of clear rules and regulations governing such acts. & 126 & 38.2 & 58 & 17.6 & 146 & 44.2 & 330 & 100 \\
Inadequate education on the rights of students on such acts & 178 & 53.9 & 25 & 7.6 & 127 & 38.5 & 330 & 100 \\
Lack of enforcement of laws governing such acts in the institution & 131 & 39.7 & 71 & 21.8 & 127 & 38.5 & 330 & 100 \\
Students' fear of school authority & 169 & 51.2 & 69 & 20.9 & 92 & 27.9 & 330 & 100 \\
Bureaucracy in dealing with such issues & 167 & 50.5 & 89 & 27.0 & 74 & 22.5 & 330 & 100 \\
Fear of victimization by the staff & 183 & 55.4 & 65 & 19.7 & 82 & 24.9 & 330 & 100 \\
Authority's inertial to deal with perpetrators of such acts & 146 & 44.2 & 114 & 34.5 & 70 & 21.3 & 330 & 100 \\
\hline
\end{tabular}

The results of the study show that majority of the students (53.9\%) believe that some sorts of corrupt practices go on in the institutions due to inadequate education on the rights of students on such acts, $51.2 \%$ think that it is due to students' fear of school authorities, $50.5 \%$ believe that it is due to bureaucracy in dealing with such issues, and $55.4 \%$ believe that it is due to students' fear of victimization by staff.

The last research question sought to ascertain the initiators of the corruptible acts. The intention was to ascertain whether it is the students who use unorthodox means to influence staff to get favour and unmerited marks in order to enhance their grades in their examinations or it is the staff who elicit it? The responses of the respondents are displayed in Table 4.

Table 4: Perceived Initiators of Corruption in Academic Institutions

\begin{tabular}{ccc}
\hline & Freq. & Percent (\%) \\
\hline Staff & 192 & 58.2 \\
Students & 155 & 40.9 \\
Both & 3 & 0.9 \\
\hline Total & 330 & 100 \\
\hline
\end{tabular}

The results of the survey show that the majority of the respondents, $172(52.1 \%)$, believe that corruption in the institutions is initiated by staff. The results also show that while $40.9 \%$ are of the view that corruption in the institutions is initiated by students less than one percent $(0.9 \%)$ holds the view that it is initiated by both staff and students.

A fellow-up issue of concern was to determine whether or not the male and female students differ in their opinions on the initiators of the corruptible acts. Thus, the research hypothesis sought to ascertain if there was a gender variation in the respondents' responses on the perceived initiators of corrupt practices in the institutions. The feedback is presented in Table 5.

Table 5: Independent t-test on Respondents' Views on Initiators of Corruptible Acts

\begin{tabular}{cccccc}
\hline & $\mathbf{N}$ & Mean & SD & Df & T \\
\hline Male & 201 & 1.48 & .52 & 328 & 654 \\
Female & 129 & 1.50 & .51 & & \\
\hline
\end{tabular}

*Significant at 0.05

The results of the t-test analysis depict that there is no significant difference in the responses. The male and female students did not differ in their views on the initiators of corruption and corruptible practices in the academic institutions. The finding suggests that both gender groups perceive staff to be the initiators of the perceived corruption and corruptible acts pervasive in the institutions.

\section{Conclusions and Recommendations}

The study endeavoured to extend the discussion of corruption of academics to the sources of the acts and conditions that serve as fertile grounds for the perpetuation of the menace in academic institutions entrusted with the responsibility of producing capable future leaders, graduate with sound knowledge, character and integrity. Although a lot of studies had been conducted on the subject, researchers had been silent on initiators of the acts and conditions that promote the 
practice. The results of the survey study revealed that favouritism, nepotism and examination malpractices are major forms of corruption perceived by the students to be pervasive in the institutions. The results further indicate that most of the students perceived staff to mostly initiate the practice more than students do. Nonetheless, there was no significant difference in the views of the male and female students on initiators of the perceived corruption practices. Both male and female students shared the view that staff usually initiate the acts more than as students may do. It also emerged from the study that inadequate education on the right of students on such acts, bureaucracy involved in dealing with corruption issues in academic institutions, fear of school authorities and students' fear of victimization are perceived by the students to be the conditions that promote the perpetuation of the practice in the academic institutions.

The study, therefore, recommends that for the fight in curbing corruption of academics to succeed, authorities ought to target the staff. The institutions ought to evolve codes of conduct to ensure high standards of integrity in the conduct of staff activities. The institution(s) that already have codes of conduct ought to ensure compliance and to allay the fears of students of victimization when they report such incidences. In view of the precarious nature of the menace, all universities need to have codes of conducts which are the ethics, rules and regulations or standards that would guide the behaviour and activities of staff and students of the institutions. Students also need to be adequately educated on their rights on such issues and be encouraged to report corruption if they experience one. Further studies could be conducted into the impact of alleged corruption on the behaviour of students who experience corruption acts during their studies in academic institutions.

\section{References}

Alutu, A. N. G. and Alutu, O. E. (2006). Unethical practices among academics as perceived by undergraduates: A case study of the University of Benin. Unpublished lead paper presented at CASSON's 30th Annual Conference held at Minna-Nigeria.

Calelkova, I. and Hanousek, J. (2004). The power of negative thinking: Corruption perception and willingness to bribe in Ukraine. Applied Economics, 36(4), 383-397.

Carr, C. S. (2011). Evolution of leadership preparation in the 21st Century. NCPEA. Educational Leadership Review, 6(1), 33-61.

Fasokun, T. O. (2010). Policy issues in poverty education through adult education. In Julie Precede (ed.). Adult education and poverty reduction: A global priority. A paper presented and published at the University of Botswana.

Eze, J. U. (2006). Counselling strategies against corrupt practices in Universities: Implications of stability in tertiary institutions. Unpublished Lead Paper presented at CASSON's 30th Annual Conference held at Minna-Nigeria.

Hallack, J. and Poison, M. (2007). Corrupt schools, corrupt universities: What can be done? Paris: UNESCO Publishing

Hallak, J. and Poison, M. (2001). Ethics and corruption in Education. Paris: IIEP- UNESCO.

Heyneman, S. P. (2010). The concern with corruption in higher education. In Tricia Bertram Gallant (eds.). Creating the ethical academy: A systems approach to understanding misconduct and empowering change. New York: Routledge and Kegan Paul.

Heyneman, S. P. (2009). Buying your way into heaven: Education and corruption in international perspective. Sense Publisher: Rotterdam/Taipei.

Heyneman, S. P., Anderson, K. H. and Nuraliyeva, N. (2007). The cost of corruption in higher education. Comparative Education Review, 52(1), 1-25.

Iddrisu, H. (2003). Zero tolerance: Public sector corruption in Ghana. Accra: Skills Graphix.

Kassahun, S. (2011). Good governance: An antidote to corruption in Africa. Journal of Sustainable Development in Africa, 13(5), 201224.

Kaufmann, D. (2005). Six questions on the cost of corruption with Daniel Kaufmann. Washington: World Bank.

Lawal, A. A. (2006). Corruption in Nigeria: A colossal legacy. Inaugural lecture. University of Oyo Press.

Meier, B. and Griffin, M. (2005). (eds.). Stealing the future: Corruption in the classroom. Transparency International: Berlin.

Mensah, S., Aboagye, A., Addo, E. and Buatsi, S. N. (2003). Corporate governance and corruption in Ghana: Empirical findings and policy implication. Accra: African Capital Markets Forum.

Mocan, N. (2004). What determines corruption?: International evidence from Micro Data. National Bureau of Economic Research Inc.

Nnodum, B. I. (2008). Corrupt practices among academics as perceived by undergraduates: Implication for counselling and national development. International Journal of Educational Research. 4(1), 141-150.

Patrinos, H. and Ruthkagia, A. (2007). Maximizing the performance systems: The case of teacher absenteeism. In the many cases of corruption.

Rumantseva, N. L. (2005). Taxonomy of corruption in higher education. Peabody Journal of Education, 80(1), 81-92.

Ruzindane, B. (1998). Corruption and national development. McGraw-Hill: New York.

Shaw, P. (2005). The determinants of educational corruption in higher education: The case of Ukraine. University of Connecticut, Connecticut.

Shelley, K. J. (2013). Corruption: It's silent penetration into the Indian education. Journal of Education and Practice, 4(1), 30-35.

Swamy, A., Knack, S., Lee, Y. and Azfar, O. (2000). Gender and corruption. Journal of Development Economics, 64, 25-55.

Temple, P. and Petrov, G. (2004). Corruption in higher education: Some findings from the former Soviet Union. Higher Education Management and Policy, 16(1), 83-99. 
Transparency International Ghana (Ghana Integrity Initiative) (2011). The "voices of the people survey": A national survey on corruption in Ghana. 